University for Business and Technology in Kosovo

UBT Knowledge Center

UBT International Conference

2017 UBT International Conference

Oct 28th, 4:00 PM - 5:30 PM

\title{
The importance of differentiated instruction in EFL learning
}

Laura Naka

University of Gjakova, laura.naka@uni-gjk.org

Follow this and additional works at: https://knowledgecenter.ubt-uni.net/conference

Part of the Education Commons

\section{Recommended Citation}

Naka, Laura, "The importance of differentiated instruction in EFL learning" (2017). UBT International Conference. 119.

https://knowledgecenter.ubt-uni.net/conference/2017/all-events/119

This Event is brought to you for free and open access by the Publication and Journals at UBT Knowledge Center. It has been accepted for inclusion in UBT International Conference by an authorized administrator of UBT Knowledge Center. For more information, please contact knowledge.center@ubt-uni.net. 


\title{
The importance of differentiated instruction in EFL learning
}

\author{
Laura Naka \\ University of Gjakova "Fehmi Agani' \\ Gjakova, Kosovo \\ laura.naka@uni-gjk.org
}

\begin{abstract}
Differentiated instructions in learning is based in the appropriate methods for learning but in fact this is the way how teachers exploit the teaching opportunities in order to provide better learning environment within their instruction. English as a foreign language learning in Kosovo has been overwhelming and in addition to the importance of English Language Learning, is also the importance of increasing the interest in more effective teaching. The most difficult challenge, that EFL teachers consider to overcome, is teaching in mixed ability classes. Mixed ability EFL classes are a composition of students with different English language level proficiency in the same class. This paper aims to explore the techniques and strategies which avoid the implementation of teaching instruction "the one-size-fits-all" and focus more on students' learning styles and their individual preferences. In order to achieve the foreseen objectives, English foreign language teacher is oriented towards choosing the right strategies, always adapting to the students' needs. It also examines the factors which cause different instructions of learning based on students' English language proficiency. Among the most controversial factors that cause diversity in the mixed ability EFL classes are: Social and cultural background, Learning ability, Previous teaching, and student's personality and Learning styles. Nevertheless, although differentiated instructions are attributed to students and learning, it seems like teachers and teaching is being challenged along this process.
\end{abstract}

Keywords: differentiated instructions, EFL learning, mixed ability classes, students' level proficiency

\section{Introduction}

Starting from elementary education, secondary education and undergraduate studies, students should learn and attend English as a second language courses in order to pass these school levels. English language learning becomes even more important if student goals are persistent. Even for an application to be employed or for further studies, English is required. In the postwar times, the knowledge of English Foreign Language (EFL) is a necessity. The purpose of young people in Kosovo nowadays is education or employment abroad. They believe, the English language skill is considered as the most important issues to reach the goal. Therefore, a lot of the universities throughout the world need to include English language as one of their educational tool requirements (Khader \& Mohammad, 2010).

Generally, learning needs to be followed by an appropriate climate so learners take its seriousness in consideration. At the same time the teacher should be careful in the progress of student's learning. Being transparent with students and enabling them to express freely to every question and request they have and will be able to fulfill their duties that were required by teacher. As (Kelly, 1974) pointed, the advice on how to work with these classes is appropriate for students of all ages and abilities. It is important for teachers to create a relaxed, positive atmosphere in the classroom (Ainslie, 1994). Hereby, they will have the chance to address the students' individual 
needs in order to make their learning process successful and meaningful to each student (Heacox, 2012; Subban, 2006; Tomlinson, 2001; Tomlinson, 2005). Based on the importance of this teaching approach the proposed study will explore for a general overview of differentiated instructions and what should be considered by EFL teachers in order to conduct instructions differently.

The paper will mainly focus on the importance of differentiated instructions in the learningteaching process in the classroom, factors that influence this differentiation, different learner's level proficiency that causes an English Language mixed ability class, problems identified as a result of these causes and how to find the solutions needed to overcome the situation, which is considered delicate by both teachers and students.

\section{The concept of differentiated instructions in learning EFL}

Differentiated instructions is the way students gain the knowledge and strategies they apply during the learning process. They will learn what the teacher approaches to all of them the same literature based on their different individual methods of learning. Not everyone has the same skills, same preferences, and the same learning style. Students demonstrate varying abilities, academic levels, learning styles, and learning preferences and need tailored instruction to meet their unique needs (Bender, 2012). Differentiated instruction recognizes the value and worth that exist in each individual: it allows students from all backgrounds and with diverse abilities to demonstrate what they know, understand, and are capable of doing (Adami, 2004). Furthermore, differentiation can be defined as the instructive approach by which teachers modify the curriculum, their teaching methods, the educational sources used, the learning activities and the evaluation methods according to and in correspondence with students' differentiated needs, in order to maximize the learning opportunities for every student (Bearne,1996).

\section{Three areas of differentiated instructions}

Differentiated instructions are based on the distinctiveness of learning in content, process and product according to students' needs and learning styles. Content is what students are to master or learn from the instruction; process is how the students must complete the learning content; and product is how the learning is demonstrated or observed (Bender, 2012; Cox, 2008). Further, content is the material that is approaching students from the teacher to learn. This material is the same for all, conforming to the syllabus designed at the beginning of the school year. The process is the methodology used, different strategies and methods to achieve content learning. Here, the students are distinguished by their styling to learn. And, ultimately, the product, which is based on the acquisition of knowledge from the proposed material through the necessary student techniques and evaluation for their interpretation.

\section{Learning styles vs EFL teaching styles}

Obviously, the ability of a student to gain knowledge and previous teaching means a lot when it comes to how much a student learns, but it also depends on the adaptation of learning styles with the EFL teacher's methodology offered in the classroom. If mismatches exist between learning styles and teaching styles students become bored and inattentive in class, do poorly on tests, get discouraged about the courses, the curricullum, and themselves, and in some cases cange to ther 
curricula or drop out of school (Felder and Silverman, 1988). The learner him/herself decides on how to happen the learning process based on their learning preferences, and also the teacher can facilitate only after she/he has identified these students' preferences. Many researchers have investigated the learning styles by giving this issue of great importance to education, and more than 70 new learning style concepts are being verified Coffield at al. (2004). So many verified learning styles and researched concepts tell us that education is more complex than that. It becomes even more complex when suggestions are made, data is derived, hypotheses are raised and theories are created and are still discussed as comparative, argumentative, unstable and with positive or negative impact, so it remains for further disccussions and recommendations. Each study starts with the positive view regarding the topic of researched paper, to continue with some disadvantages and again to conclude that it is useful aim. Similarly, here it comes the challenge of teaching methodology and difficulties to meet students' learning styles and possibility to reach this goal. According to (Thousand, Villa, \& Nevin, 2007) teachers must first collect information about their students so that they can discover how diverse the population in their class is and start considering which types of teaching strategies, teaching methods, evaluation options, and materials they are going to use in order to develop their teaching plans applying differentiated instruction based on that teaching framework. The ways students prefer to learn - referring to the types of intelligences students have: linguistic, logical/mathematical, visual/spatial, kinesthetic, musical, naturalistic, interpersonal, and intrapersonal- are also important aspects to provide students with appropriate instruction when dealing with the form we approach content to them (Thousand, Villa, \& Nevin, 2007).

Prior to the implementation of any strategies, differentiating instruction starts as a simple mindset of a teacher, an understanding that each child brings their own memories and own previous experiences to class with them and that each one of them has their own areas of strength, areas that need to be strengthened, emotions, feelings and attitudes and most important of all, that each one of them can learn (Gregory, Chapman, 2013). The absence of the implementation of these strategies causes discouragement to students. The weaker students can fall too far behind to ever catch up and the stronger students can lose their motivation and interest in a subject in which they originally had a lot of potential (Caldwell, 2012).

\section{Factors that influence differentiation instructions among EFL learners}

There are several factors that cause diversity in the mixed ability EFL classes. Among the most controversial factors in the teachers' community of teachers are as follows. Social and cultural background is a factor connected with the student's school and family background, his/her position in society and family and relationship, parental education and the importance they give to their child's education, gender influences, and the environment and conditions in which they live. Learning ability is another cause which has to do with the motivation to learn, talent and desire to gain knowledge, the ability to avoid gaps, disability to ask teacher's help and to communicate with classmates, demoralization from unsuccessful success so far, etc. Previous teaching affects whether positively or negatively in students' knowledge acquisition based on teacher's professional development of EFL language who taught them during the previous education, teacher's experience, teaching methodology, creativity and the way teacher manages the classroom. Each student's personality is valued by taking into account their ambitions, problem solving skills, strength and weaknesses, his/her approach to studies, lack of confidence or overconfidence, sense of responsibilities, etc. Learning styles are the different learning ways that each individual chooses to achieve the goal. According to Keefe (1979): Learning styles are "characteristic cognitive, affective, and psychological behaviors that serve as relatively stable indicators of how learners perceive, interact with, and respond to the learning environment". 
From these assumptions it is considered that factors which cause mixed ability English Language classes are numbered as a result of many differences in human genetics or the creation of human identity by the way of life. Sternberg (1997) claimed that even a minimal amount of differentiation made a difference in student achievement.

\section{EFL mixed ability class}

The main cause that differentiated instructions function are mixed ability classes. Mixed ability classes are formed as a result of the factors mentioned above and cannot be ignored. Mixed ability EFL classes are a composition of students with different English language level proficiency. Baker (2002) indicates that it is not just the fact that there are many students in a class, but that all of them are at so many different ability levels that provide the biggest challenge. All of them suffer the consequences of each other. Students have their own way of learning, and the weaker ones probably have more difficulties working in a noisy atmosphere since they are usually more easily distracted (Kelly, 1974). While advanced students concentrate on the given task and require immediate feedback from the teacher without having the patience to wait their classmates. Some teachers try to engage them with additional tasks, but, as Tomlinson (1995) emphasized, this could be seen as punitive for them. Bowman (1992) stated: "Students are very resourceful. They can create problems or generate solutions, depending on how you engage and maintain their attention". Given this fact, it is important for teachers to create a relaxed, positive atmosphere in the classroom (Ainslie, 1994).

\section{Mixed Ability Classes: Causes, Problems, Solutions}

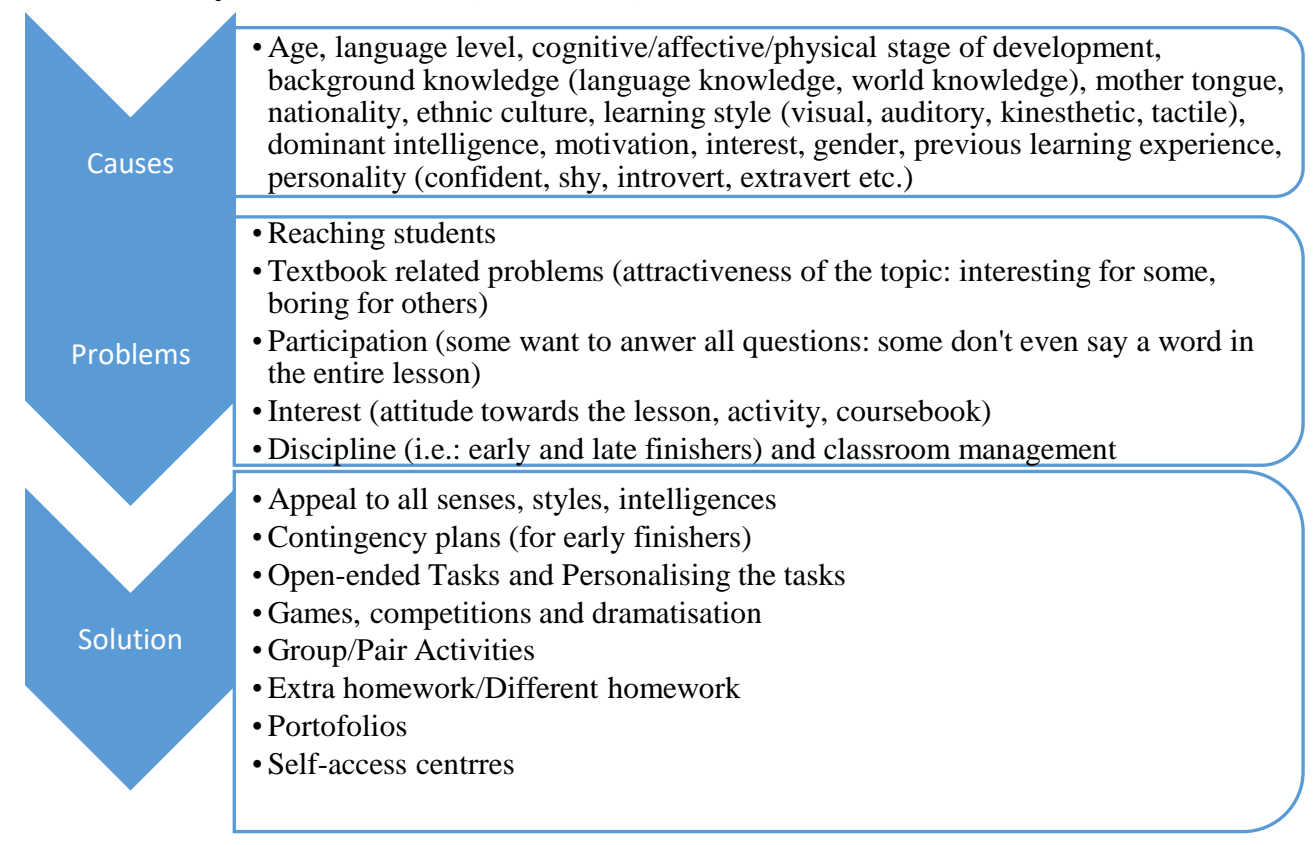


Adapted from: Şallı-Çopur, D. (2005). Coping with the problems of mixed ability classes. The Internet TESL Journal, 11 (8). Retrieved from: http://iteslj.org/Techniques/Salli-CopurMixedAbility.html

\section{Summary}

The community of English Foreign Language teachers needs working to establish some key differentiated instructional strategies that help learners to gain knowledge as easily and efficiently as possible for the motivation of students for efficient learning that also realizes the goal of all educational components, the development of quality in education. It is welcomed a preliminary survey for students at the beginning of the academic year to determine the methods and strategies needed for differentiated instructions, helpful for designing an appropriate syllabus that includes the methodology and learning outcomes as well. Based on the literature review and some of the experiences that teachers have encountered during the learning-teaching process in mixed classes, the practice of adapting students' learning methods does not seem as possible as expressed in theory. However, this is not a choice but a need. Therefore, the teacher in the very beginning should investigate the students' learning styles by giving them chance to express ways they learn easily and efficiently. That would surely help to be flexible in the teaching methodology during designing the syllabus, including here the evaluation of group work, peer work, individual work, etc.

\section{References:}

1. Adami, A.F. (2004). Enhancing students' learning through differentiated approaches to teaching and learning: A Maltese perspective. Journal of Research in Special Educational Needs, 4 (2), 91-97.

2. Ainslie, Susan. (1994). Mixed Ability Teaching: Meeting Learners 'needs. Netword 3: Teaching Language to Adults. London: Centre for Information on Language Teaching and Research

3. Bearne, E. (Ed.). (1996). Differentiation and diversity in the primary school. London: Routledge.

4. Baker, Joanna. (2000). The English language teacher's handbook: how to teach large classes with few resources. New York: Continuum; London: Cassel.

5. Bender, W.N. (2012). Differentiating instruction for students with learning disabilities: New bast practices for general and special educators (3rd Edition). Thousand Oaks, CA: Crowin.

6. Bowman, Brenda. (1992). Teaching English as a Foreign Language to Large Multilevel Classes. Washington, DC: Center for Applied Linguistics.

7. Caldwell, D. W. (2012). Educating Gifted Students in the Regular Classroom: Efficiency, Attitudes, and Differentiation of Instruction. Electronic Theses \& Dissertations. Paper 822.

8. Coffield, F., Moseley, D., Hall, E., and Ecclestone, K. (2004). Learning Styles and Pedagogy in Post 16 Learning: A Systematic and Critical Review. London: Learning and Skills Research Centre.

9. Cox, S.G. (2008). Differentiated instruction in the elementary classroom. Education Digest: Essential Readings Condensed for Quick Review, 73(9), 52-54.

10. Felder, R.M., \& Silverman, L.K. (1988). Learning and teaching styles in engineering education, Engr. Education, 78(1), 674-681. 
11. Gregory, G. \& Chapman, C. (2013.) Differentiated Instructional Strategies: One Size Doesn't Fit All. Corwin, Thousand Oaks, CA, USA. Retrieved June 232017 from https://repository.ffri.uniri.hr

12. Heacox, D. (2012). Differentiating instruction in the regular classroom: How to reach and teach all learners. Minneapolis: Free Spirit Publishing Inc.

13. Keefe, J.W. (1979) Learning style: An overview. NASSP's Student learning styles: Diagnosing and proscribing programs (pp. 1-17). Reston, VA. National Association of Secondary School Principles.

14. Kelly, A.V. (1974). Teaching mixed ability classes: an individualized approach. London: Harper \& Row Ltd.

15. Khader, K. T., \& Mohammad, S. (2010). Reasons behind non-English major University

16. Students' achievement gap in the English language in Gaza strip from students' perspectives

17. Factors Causes Students Low English Language Learning: A Case Study in the National University of Laos (PDF Download Available). Available from: https://www.researchgate.net/publication/234556706_Factors_Causes_Students_Low_Eng lish_Language_Learning_A_Case_Study_in_the_National_University_of_Laos [accessed May 22, 2017].

18. Şall1-Çopur, D. (2005). Coping with the problems of mixed ability classes. The Internet TESL Journal, 11 (8). Retrieved from: http://iteslj.org/Techniques/Salli-CopurMixedAbility.html

19. Subban, P. (2006). Differentiated instruction: a research basis. International Education Journal, 7(7), 935-947.

20. Sternberg, R. (1997). What does it mean to be smart? Educational Leadership, 54(6), 20.

21. Tomlinson, C. (1995a). How to differentiate instruction in mixed-ability classrooms. Alexandria, VA: Association for Supervision and Curriculum Development.

22. Tomlinson, C. (1995b). Deciding to differentiate instruction in middle school: One school's journey. Gifted Child Quarterly, 39, 77-87.

23. Tomlinson, C. (2001). How to differentiate instruction in mixed-ability classrooms (2nd ed.). Alexandria, VA: Association for Supervision and Curriculum Development.

24. Tomlinson, C. A. (2005). The differentiated classroom: Responding to the needs of all learners. Upper Saddle River, NJ: Pearson Education. 